\title{
Discussion of papers of Dr Pachalski and R McAdam and Dr H. Natvig
}

\author{
Chairman: Professor V. PAESLACK
}

DR HAMza $(E g y p t)$. Really I was impressed by this paper, but I think if the author adds to his cardiovascular assessment maximum oxygen consumption and if he can carry next time lactic acid it would be worth these two tests, as all of us know, are accurate tests more than vital capacity. Thank you.

DR PACHALsKi (Poland). We measure the vital capacity in this. We measure the cardiorespiratory efficiency in Skabinski's cardiorespiratory index. It was one slide but I see that it is not on the table.

Sir Ludwig GutTmanN (G.B.). I would really like to congratulate Professor Pachalski on his paper which really confirms more or less other experimental studies which were done by our Canadian friends during the Olympic Games in Toronto in 1976. That your results coincide very much shows that your studies were carried out very thoroughly.

DR EL Toraei (U.S.A.). I have two questions, the first one is on the high level of cord injuries you used in your technique and the second is what was the incidence of falls with or without fractures?

Dr Natvig (Norway). The highest incident was Ti lesion. When it comes to fractures I didn't quite understand your question.

Dr El ToRAEI (U.S.A.). Was it falls due to the training?

DR Natvig. Before we teach the patients to go upstairs we teach them how to fall properly and we have a session of about a week on how to fall and how to get up again, so we didn't have any fractures.

Prof. Weiss (Poland). I observed for a long time this work in Oslo with great admiration. This is how we make our compensations for stability from a neurophysiological point of view. These people are highly motivated in Norway in the words of our presenter here and they have to be motivated because they encounter in their lives so many barriers of different kinds like snow, like difficulties in mountain climbing, they should know how to walk, and this stair programme is very capable and I think I can only congratulate you because you really show how immense and unlimited are the compensations for disabilities of human beings. You can only use it of course in the cold climate such as Norway and Switzerland. I was asked once in Miami why do they walk in braces and I said Yes in Poland they walk. I don't believe they walk in Miami.

DR Natvig. Thank you very much, Professor Weiss. I do not quite agree that one should only do this in the Nordic zones. I believe that you have very great sportsmen even in Miami.

DR NUSEIBEH (G.B.). Can I ask what type of walk you teach them, because if it is a four-point walk to walk roo yards it would take them practically 2 or 3 hours to do it, while the swing through is very quick.

DR NATVIG. Swing through.

DR YEO (Australia). I wonder if you could tell us what the calipers are made from, if you have an alloy or a steel caliper.

DR Natvig. Is Dr Johnson here? Perhaps you could walk for us and perhaps you would be so kind as to show us your calipers. He is a complete TI2 and he learned to walk in 1964 when he had his injury. [Demonstration.] Thank you very much. If you turn around and show them your calipers.

USA VoICE. How many overweight patients walk, Dr Natvig?

DR NATVig. I can't tell you that because there was no weight compiled in this series.

USA VoICE. How are the shoulders, you have been walking for how many years?

DR JoHnson (Norway). I5 years. 
USA VoICE. How are your shoulders, any periarthritis or tendinitis?

DR Johnson. I never had any treatment for those things.

USA VoICE. No elbow pain?

Dr Johnson. Well, I get elbow pain but that is from another sport I do and that is pushing the wheelchair with ski sticks.

SIR LUDWIG GUTTMANN (G.B.). This was a very fine demonstration whether or not a paraplegic can walk. This reminds me of a discussion we had a few years ago in Cleveland where a leading orthopaedic surgeon said quite seriously 'I've never seen a paraplegic walk'. I think he changed his mind after he came to Stoke Mandeville and Hans Frankel, without knowing of our discussion, demonstrated with a T6 lesion walking like this fellow has just shown us. Of course it is absolutely essential that every paraplegic up to T6 or -.8 has to be taught the various types of walk. For higher lesions of course the best type of walk is the 'walking-to gait', but for lower lesions they must be able to use the 'walking-through' gait. The most safe but very slow is the four-point gait, and all this has to be taken. I am very glad, Natvig, that you showed the importance of stair walking. You yourself with Mr McAdam, who as you know was one of my earliest pupils, and he was the man I remember very well, and he trained his patients walking upstairs, downstairs ad nauseum, but whether the people afterwards use the walking, that is not our concern really. We have done the right thing to teach the people, whether they use it, whether that is their personality, whether they are employed or whether they want to be employed, and whether walking or climbing stairs can help them, but we should never give up our tendency to teach the people while they are under our observation, to give them the best possibility to commence walking.

PROFESSOR PAesLACK. Thank you, Sir Ludwig. I think we are at the end for this afternoon with some excellent presentations, and we had some good discussions. May I thank all the speakers and all the people that took part in the discussions. 